\title{
Comparative study of shell choice by the southern endemic hermit crab Loxopagurus loxochelis from Brazil and Argentina
}

\author{
Estudio comparativo sobre elección de conchas en el cangrejo ermitaño endémico del \\ Atlántico sudoccidental Loxopagurus loxochelis de Brasil y Argentina
}

\author{
RENATA BIAGI ${ }^{1}$, ANDREA L. MEIRELES ${ }^{1}$, MARCELO A. SCELZO $^{2}$
}

\& FERNANDO L. MANTELATTO ${ }^{1, *}$

\begin{abstract}
${ }^{1}$ Laboratório de Bioecologia e Sistemática de Crustáceos, Departamento de Biologia, Faculdade de Filosofia, Ciências e Letras de Ribeirão Preto (FFCLRP), Programa de Pós-graduação em Biologia Comparada, Universidade de São Paulo (USP), Av. Bandeirantes 3900, CEP 14040-901, Ribeirão Preto, São Paulo, Brazil ${ }^{2}$ Departamento de Ciencias Marinas, Facultad de Ciencias Exactas y Naturales, Universidad Nacional de Mar del Plata \& CONICET, Funes 3350, 7600 Mar del Plata, Argentina

*e-mail for correspondence: flmantel@usp.br
\end{abstract}

\begin{abstract}
This study aimed to determine the shell choice pattern of the southern Atlantic endemic hermit crab Loxopagurus loxochelis from two different biogeographic provinces in Brazil and Argentina. Size and shell species preferences were determined for the two most occupied shell types (i.e., Olivancillaria urceus and Buccinanops gradatum) in Caraguatatuba region (Brazil) and in Mar del Plata (Argentina). Shell occupation was analyzed considering the biometric characteristics of shells, the occurrence of shell types, and the preference of the hermit crabs for the most frequently occupied shell species. Samples were taken using otter trawl in the infralittoral area of both regions and the animals captured were measured and weighed. Shells were identified, weighed, measured and their internal volume calculated. Experiments were accomplished in aquaria where the hermit crabs were allocated together with a sufficient number of adequate sized shells. In laboratory, L. loxochelis from Argentina presented no preference for any of the two offered shell species, while the specimens from Brazil significantly preferred $B$. gradatum shells. It was observed that the relation between shell dimensions and shell weight were the variables that best explained the association between hermit crabs and shells. Considering that Argentinean specimens are larger than the Brazilian ones we may infer that body size is a relevant factor to explain the observed differences found in relation to shell type preference.
\end{abstract}

Key words: shell preference, Anomura, Loxopagurus loxochelis.

\section{RESUMEN}

Este estudio tuvo por objetivo determinar la forma de elección de conchas de caracoles por el cangrejo ermitaño endémico del Atlántico sudoccidental Loxopagurus loxochelis proveniente de dos provincias biogeográficas de Brasil y Argentina. Se determinaron las tallas y las preferencias de conchas entre los dos tipos de caracoles más ocupados (Olivancillaria urceus y Buccinanops gradatum) en la región de Caraguatatuba (Brazil) y en Mar del Plata (Argentina). La composición de las conchas fue analizada por las características biométricas y ocurrencia de los tipos de conchas y la selección por la preferencia del cangrejo ermitaño en relación a la especie de concha más ocupada. Las muestras fueron tomadas usando redes de arrastre en las áreas infralitorales de ambas regiones y los animales capturados fueron medidos y pesados. Las conchas de caracoles fueron identificadas, pesadas, medidas y calculado el volumen interno. Las experiencias fueron realizadas en acuarios donde los cangrejos ermitaños fueron ubicados con un número suficiente y adecuado de conchas de caracoles. En el laboratorio, L. loxochelis de Argentina no presentaron diferencias entre las dos especies de conchas ofrecidas, mientras los especímenes de Brasil prefirieron conchas de $B$. gradatum en forma significativa. Se observó que las relaciones de las dimensiones y los pesos de las conchas fueron aquellas que mejor reflejaron la asociación con los cangrejos ermitaños. Teniendo en consideración que los especímenes de Argentina fueron más grandes, se puede inferir que ello puede ser uno de los factores influenciando en las diferencias por las preferencias de los tipos de conchas halladas.

Palabras clave: preferencia de conchas, Anomura, Loxopagurus loxochelis. 


\section{INTRODUCTION}

The behavior patterns of hermit crabs related to shell selection showed that this process is not by chance, but based on adequacy and availability of resources to the hermit crabs (Reese 1962, Conover 1978). Nevertheless, the specific parameters by which a shell is chosen are uncertain. Besides shell availability, almost all physical parameters have been considered in this assessment. In this manner, each shell variable has been shown to be important to different species of hermit crabs (Reese 1962, Conover 1978, Blackstone 1985, Wilber 1990, Rodrigues et al. 2000). Moreover, the fitness of a particular shell may differ between hermit crabs species, reflecting several selection pressures, which associated with different habitats, act in different ways on each crab species (Bertness 1981), in different areas (Garcia \& Mantelatto 2000). Although the shell selection process has been well investigated (Vance 1972, Elwood et al. 1979, Bertness 1980, Wilber 1990, Hazlett 1992, 1996, Siu \& Lee 1992, Ohmori et al. 1995, Wada et al. 1997, Garcia \& Mantelatto 2001), there is a scarcity of studies comparing populations from different locations. Loxopagurus Forest, 1964 is a monotypic hermit crab genus represented by Loxopagurus loxochelis (Moreira, 1901), endemic to the southwestern Atlantic coast, and occurring in Brazil (Bahia to Rio Grande do Sul States), Uruguay, and Argentina (Melo 1999). The life cycle of L. loxochelis is reasonably well known in the Ubatuba region (see Martinelli et al. 2002 for a review), as well as some aspects of sperm morphology (Scelzo et al. 2004) and taxonomic status (Mantelatto et al. 2006), but the biology of this species from other areas as Argentina is poorly known except for some information on planktonic larvae (Scelzo 1976). Recent investigations on sequences of the $16 \mathrm{~S}$ ribosomal gene made by one of us (FL Mantelatto) have showed that no marked genetic variability occurs among populations of L. loxochelis from Brazil and Argentina. Despite of this characteristic, some preliminary results have detected ecological differences on distribution, and size of the animals among the above mentioned populations (Mantelatto \& Scelzo unpublished results). Therefore, we decided to evaluate the shell size and shell species preference by
Loxopagurus loxochelis from two populations located in different biogeographical provinces, in order to compare the mechanisms of shell selection as part of a long term comparative project to study the ecology and systematics of hermit crab fauna from both Argentinean and Brazilian provinces.

\section{MATERIAL AND METHODS}

Hermit crabs were collected in Caraguatatuba $\left(23^{\circ} \mathrm{S}\right)$ (São Paulo, Brazil) during 2002 and in Mar del Plata $\left(38^{\circ} \mathrm{S}\right)$ (Buenos Aires Province, Argentina) during 2003 by a fishery boat equipped with otter-trawl nets. The both localities of study are approximately distant around $5,000 \mathrm{~km}$ from each other. After collection the animals were transported to the respective laboratories where experiments were conducted using glass aquaria with flowing sea water. Each animal was utilized only once to avoid any acquired behavior. The animals that died during the experiments were not included in the analysis. To determine correlations between characteristics of hermit crabs and their preferred shells, regression analyses were computed. The chi-square test $\left(\chi^{2}\right)$ was used to compare occupancy of shell species, and morphometric relationships were established by regression analysis and correlation coefficients (r). Shell size preference data were analyzed using the simple linear regression: $\ln \mathrm{Y}=a+$ $b \operatorname{lnX}$ (where $\mathrm{Y}=$ shell measurements: SAW = shell aperture width; SDW = shell dry weight; $\mathrm{SIV}=$ shell internal volume, and $\mathrm{X}=$ hermit crab measurements: $\mathrm{SL}=$ shield length, and $\mathrm{W}$ $=$ hermit weight). All shell-species experiments were conducted for the two most occupied shell species found at the field (Buccinanops gradatum and Olivancillaria urceus) in Brazilian waters (Martinelli \& Mantelatto 1999) and in Argentinean waters (Scelzo unpublished results).

\section{Shell-species preference}

All experiments were conducted in a pair-wise fashion. In these tests, 15 naked hermit crabs were placed in the aquaria with 150 empty shells (75 of each species) of two different species and various and adequate sizes $(O$. urceus shells ranging from 4.3 to $11.2 \mathrm{~mm} \mathrm{SAW}$ 
and $B$. gradatum shells ranging from 5.7 to $22.5 \mathrm{~mm}$ ). After $36 \mathrm{~h}$, the hermit crabs were removed from the preferred shell, and both were measured as described above for the shellsize experiments. Each test was performed in triplicate for each hermit crab origin (Argentina and Brazil).

\section{Shell-size preference}

The experiments were conducted for each of the two shell species separately (Buccinanops gradatum and Olivancillaria urceus). In each test, 15 naked hermit crabs were placed in aquaria with a minimum of 150 empty shells (10 shells per hermit crab) of various and adequate sizes. After $36 \mathrm{~h}$ in this free-choice situation, hermit crabs were removed from their chosen shell by submerging the apex of the shell in hot water (Garcia \& Mantelatto 2001), weighed (W) and measured for SL. Shell species were identified and the SDW, SAW, and SIV determined. Measurements were made directly on the specimens with a caliper $(0.1 \mathrm{~mm})$ or on drawings made with the aid of a camera lucida. Tests were replicated three times.

\section{RESULTS}

\section{Shell-species preference}

A total of 75 animals were utilized (animals SL ranging from 4.7 to $9.1 \mathrm{~mm}$ in Argentina and from 4.3 to $7.5 \mathrm{~mm}$ in Brazil). No significant preference for any of the two shell species by the Argentinean specimens $(\mathrm{P}>0.05)$ was observed. Nevertheless, there were differences in shell species selection by the hermit crabs from Brazil, being shells of $B$. gradatum significantly $(\mathrm{P}<0.05)$ preferred (Table 1$)$. In general, the morphometric relationships that best described the association between Brazilian hermit crabs and their selected shells species were those involving shell dimensions and hermit weight, independently of the shell species (Table 2).

\section{Shell-size preference}

During shell-size experiments, a total of 146 animals were utilized (animals SL ranging from 4.7 to $11 \mathrm{~mm}$ in Argentina and from 3.1 to 7.3 $\mathrm{mm}$ in Brazil). Independently of the shell species and region, all the morphometric relations demonstrated the suitable association between hermit crabs and their selected shells (Table 3).

\section{DISCUSSION}

\section{Shell-size preference}

Shell preferences, as shown by laboratory choice experiments, are important determinants of shell utilization under natural conditions (Garcia \& Mantelatto 2001). In shell selection experiments, the size of the selected shells was strongly correlated with the size of the hermit crabs. Lively (1988) experimentally manipulated the shell mass, and suggested that volume is more important than weight during the shell-size selection by hermit crabs. Mantelatto \& Dominciano (2002) conducted experiments of shell selection with Paguristes tortugae and found the best correlation coefficients between SDW and the dimensions of the hermit crabs. Thus, after observing the great variation in patterns of shell occupation

TABLE 1

Preference by Loxopagurus loxochelis for shells of two species of gastropods offered experimentally $(*=$ significant correlation, $\mathrm{P}<0.05 ; \mathrm{ns}=$ non significant correlation)

Preferencia de Loxopagurus loxochelis por conchillas de dos especies de caracoles ofrecidas experimentalmente ( $*$ correlación estadística significativa $, \mathrm{P}<0,05 ; \mathrm{ns}=$ correlación estadística no significativa $)$

\begin{tabular}{|c|c|c|c|c|}
\hline Site studied & $\mathrm{Sp}$ & & $\mathrm{n}$ & Choice $1: 2$ \\
\hline Brazil & $B$.gradatum & O. urceus & 43 & $43: 0 *$ \\
\hline Argentina & B. gradatum & O. urceus & 32 & $15: 17^{\mathrm{ns}}$ \\
\hline
\end{tabular}


among different hermit crab populations (Conover 1978, Blackstone 1985, Wilber 1990, Rodrigues et al. 2000, Garcia \& Mantelatto 2001, Mantelatto \& Dominciano 2002, Mantelatto \& Meireles 2004), we may infer about the existence of shell selection in hermit crabs varying according to shell dimensions, but also depending on hermit crab species, the origin of the population as well as the availability of resources in the area of occurrence. The correlation coefficients obtained from shell-size selection were similar for both shell species: $O$. urceus and $B$. gradatum. Such pattern of shell selection might be considered beneficial to the hermit crab's population because it provides more than one option favorable to occupancy, since the two most occupied shell species provided both good correlation coefficients.

\section{Shell-species preference}

The absence of shell species preference under laboratory conditions was found by Orians \& King (1964) for Pagurus samuelis and Pagurus granosimanus, by Siu \& Lee (1992) for Clibanarius bimaculatus and Garcia \& Mantelatto (2001) for Calcinus tibicen. However, in other studies the hermit crabs chose, in laboratory, the shell species most occupied in the field (Abrams 1978, Elwood et al. 1979, Siu \& Lee 1992, Ohmori et al. 1995, Hahn 1998). In the present study the populations of the same species presented different shell choice patterns. While specimens from Brazil chose $B$. gradatum shells in spite of $O$. urceus, specimens from Argentina presented no significant shell type preference.

TABLE 2

Regression equations for Brazilian and Argentinean chosen shell species $(\mathrm{r}=$ correlation coefficient; $\mathrm{SL}=$ shield length; $\mathrm{W}=$ hermit crab weight; SAW = shell aperture width; $\mathrm{SAL}=$ shell aperture length; SIV = shell internal volume; SDW = shell dry weight; $*$ = significant correlation, $\mathrm{P}$

$$
<0.05)
$$

Ecuaciones de regresión para las especies de caracoles de Brasil y Argentina seleccionadas ( $\mathrm{r}=$ coeficiente de correlación; $\mathrm{SL}=$ largo del escudo; $\mathrm{W}=$ peso del cangrejo ermitaño; $\mathrm{SAW}=$ ancho de la abertura de la concha; $\mathrm{SAL}=$ largo de la abertura de la concha; SIV = volumen interno de la concha; SDW = peso seco de la concha; $*$ = correlación estadística significativa, $\mathrm{P}<0,05)$

\begin{tabular}{|c|c|c|c|c|c|}
\hline Site studied & $\mathrm{n}$ & Relation & $\begin{array}{l}\text { Exponential equation } \\
\mathrm{Y}=\mathrm{a} \mathrm{X}^{\mathrm{b}}\end{array}$ & $\begin{array}{l}\text { Linearized equation } \\
\ln Y=\ln a+b \ln X\end{array}$ & r-value \\
\hline \multirow{8}{*}{ Brazil } & 42 & SAW x SL & $\mathrm{SAW}=1.12 \mathrm{SL}^{1.22}$ & $\ln \mathrm{SAW}=0.11+0.20 \ln \mathrm{SL}$ & $0.85 *$ \\
\hline & 42 & SAL x SL & $\mathrm{SAL}=3.03 \mathrm{SL}^{1.07}$ & $\ln \mathrm{SAL}=6.23+0.68 \ln \mathrm{SL}$ & $0.85^{*}$ \\
\hline & 42 & SDW x SL & $\mathrm{SDW}=0.02 \mathrm{SL}^{2.85}$ & $\ln \mathrm{SDW}=-3.91+1.05 \ln \mathrm{SL}$ & $0.76^{*}$ \\
\hline & 41 & SIV x SL & $\mathrm{SIV}=0.006 \mathrm{SL}^{3.56}$ & $\ln \mathrm{SIV}=-5.11+1.27 \ln \mathrm{SL}$ & $0.80 *$ \\
\hline & 42 & SAW x W & $\mathrm{SAW}=8.58 \mathrm{~W}^{0.35}$ & $\ln \mathrm{SAW}=2.15-1.05 \ln \mathrm{W}$ & $0.90 *$ \\
\hline & 42 & SAL $x \mathrm{~W}$ & $\mathrm{SAL}=18.16 \mathrm{~W}^{0.31}$ & $\ln \mathrm{SAL}=2.90-1.17 \ln \mathrm{W}$ & $0.89 *$ \\
\hline & 42 & SDW x W & $\mathrm{SDW}=3.19 \mathrm{~W}^{0.82}$ & $\ln \mathrm{SDW}=1.16-1.20 \ln \mathrm{W}$ & $0.81 *$ \\
\hline & 41 & SIV x W & $\mathrm{SIV}=2.13 \mathrm{~W}^{1.04}$ & $\ln \mathrm{SIV}=0.76+0.04 \ln \mathrm{W}$ & $0.86^{*}$ \\
\hline \multirow{8}{*}{ Argentina } & 32 & SAW x SL & $\mathrm{SAW}=3.54 \mathrm{SL}^{1.13}$ & $\ln \mathrm{SAW}=1.26+0.12 \ln \mathrm{SL}$ & $0.76^{*}$ \\
\hline & 32 & SAL x SL & $\mathrm{SAL}=3.64 \mathrm{SL}^{0.60}$ & $\ln \mathrm{SAL}=1.29-0.51 \ln \mathrm{SL}$ & $0.54 *$ \\
\hline & 32 & SDW x SL & $\mathrm{SDW}=0.03 \mathrm{SL}^{3.09}$ & $\ln \mathrm{SDW}=-3.50+1.13 \ln \mathrm{SL}$ & $0.76^{*}$ \\
\hline & 32 & SIV x SL & $\mathrm{SIV}=0.06 \mathrm{SL}^{2.30}$ & $\ln \mathrm{SIV}=-2.81+0.83 \ln \mathrm{SL}$ & $0.75 *$ \\
\hline & 32 & SAW x W & $\mathrm{SAW}=25.43 \mathrm{~W}^{0.12}$ & $\ln \mathrm{SAW}=3.24-2.12 \ln \mathrm{W}$ & $0.36^{*}$ \\
\hline & 32 & SAL $x \mathrm{~W}$ & $\mathrm{SAL}=10.51 \mathrm{~W}^{0.05}$ & $\ln \mathrm{SAL}=2.35-2.12 \ln \mathrm{W}$ & 0.19 \\
\hline & 32 & SDW $x$ W & $\mathrm{SDW}=5.87 \mathrm{~W}^{0.31}$ & $\ln \mathrm{SDW}=1.77-1.17 \ln \mathrm{W}$ & $0.34 *$ \\
\hline & 32 & SIV x W & $\mathrm{SIV}=3.84 \mathrm{~W}^{0.16}$ & $\ln \mathrm{SIV}=1.34-1.83 \ln \mathrm{W}$ & 0.23 \\
\hline
\end{tabular}


TABLE 3

Regression equations for each chosen shell size $(\mathrm{r}=$ correlation coefficient; $\mathrm{SL}=$ shield length; $\mathrm{W}=$ hermit crab weight; SAW = shell aperture width; SAL = shell aperture length; SDW = shell dry weight; SIV = shell internal volume; $*$ = significant correlation, $\mathrm{P}<0.05$ )

Ecuaciones de regresión para cada una de las tallas de las conchas seleccionadas $(r=$ coeficiente de correlación; SL $=$ largo del escudo; $\mathrm{W}=$ peso del cangrejo ermitaño; SAW = ancho de la abertura de la concha; SAL = largo de la abertura de la concha; SIV = volumen interno de la concha; SDW = peso seco de la concha; $*$ = correlación estadística significativa, $\mathrm{P}<0,05)$

\begin{tabular}{|c|c|c|c|c|c|}
\hline Site studied & Species & $\mathrm{n}$ & Relation & Transformed equation $\ln Y=\ln a+b \ln X$ & r-value \\
\hline \multirow[t]{16}{*}{ Brazil } & & 44 & SAW $\times$ SL & $\ln \mathrm{SAW}=0.50-0.01 \ln \mathrm{SL}$ & $0.69 *$ \\
\hline & & 44 & SAL x SL & $\ln \mathrm{SAL}=1.27-0.01 \ln \mathrm{SL}$ & $0.75 *$ \\
\hline & B. gradatum & 44 & SDW $\times$ SL & $\ln \mathrm{SDW}=-1.97+0.66 \ln \mathrm{SL}$ & $0.60 *$ \\
\hline & & 43 & SIV x SL & $\ln \mathrm{SIV}=-5.30+1.27 \ln \mathrm{SL}$ & $0.59 *$ \\
\hline & & 44 & SAW x W & $\ln \mathrm{SAW}=2.12-1.10 \ln \mathrm{W}$ & $0.90 *$ \\
\hline & & 44 & SAL x W & $\ln \mathrm{SAL}=2.88-1.17 \ln \mathrm{W}$ & $0.94 *$ \\
\hline & & 44 & SDW x W & $\ln \mathrm{SDW}=1.15-0.40 \ln \mathrm{W}$ & $0.82 *$ \\
\hline & & 43 & SIV $x \mathrm{~W}$ & $\ln \mathrm{SIV}=-0.27-0.03 \ln \mathrm{W}$ & $0.64 *$ \\
\hline & & 39 & SAW $\times$ SL & $\ln \mathrm{SAW}=0.38-0.04 \ln \mathrm{SL}$ & $0.84 *$ \\
\hline & & 39 & SAL x SL & $\ln \mathrm{SAL}=1.79-0.22 \ln \mathrm{SL}$ & $0.82 *$ \\
\hline & & 39 & SDW $\times$ SL & $\ln \mathrm{SDW}=-1.71+0.75 \ln \mathrm{SL}$ & $0.77 *$ \\
\hline & O. urceus & 39 & SIV x SL & $\ln \mathrm{SIV}=-3.91+0.99 \ln \mathrm{SL}$ & $0.84 *$ \\
\hline & & 39 & SAW x W & $\ln \mathrm{SAW}=1.98-1.27 \ln \mathrm{W}$ & $0.92 *$ \\
\hline & & 39 & SAL $x \mathrm{~W}$ & $\ln \mathrm{SAL}=3.12-1.43 \ln \mathrm{W}$ & $0.91 *$ \\
\hline & & 39 & SDW x W & $\ln \mathrm{SDW}=1.77-0.46 \ln \mathrm{W}$ & $0.86^{*}$ \\
\hline & & 39 & SIV $x \mathrm{~W}$ & $\ln \mathrm{SIV}=0.69-0.25 \ln \mathrm{W}$ & $0.94 *$ \\
\hline \multirow[t]{16}{*}{ Argentina } & & 33 & SAW x SL & $\ln \mathrm{SAW}=1.48-0.04 \ln \mathrm{SL}$ & $0.70^{*}$ \\
\hline & & 33 & SAL x SL & $\ln \mathrm{SAL}=0.70-0.02 \ln \mathrm{SL}$ & $0.70 *$ \\
\hline & B. gradatum & 33 & SDW $\times$ SL & $\ln \mathrm{SDW}=-1.11+0.47 \ln \mathrm{SL}$ & $0.52 *$ \\
\hline & & 30 & SIV $\times$ SL & $\ln \mathrm{SIV}=-4.60+1.16 \ln \mathrm{SL}$ & $0.81 *$ \\
\hline & & 32 & SAW $x$ W & $\ln \mathrm{SAW}=1.40-0.33 \ln \mathrm{W}$ & $0.73 *$ \\
\hline & & 32 & SAL $x \mathrm{~W}$ & $\ln \mathrm{SAL}=1.06-0.31 \ln \mathrm{W}$ & $0.72 *$ \\
\hline & & 32 & SDW $\times$ W & $\ln \mathrm{SDW}=0.14-0.19 \ln \mathrm{W}$ & $0.54 *$ \\
\hline & & 29 & SIV x W & $\ln \mathrm{SIV}=-4.71-3.50 \ln \mathrm{W}$ & $0.85^{*}$ \\
\hline & & 30 & SAW x SL & $\ln \mathrm{SAW}=2.57-0.61 \ln \mathrm{SL}$ & $0.67 *$ \\
\hline & & 30 & SAL x SL & $\ln \mathrm{SAL}=1.17-0.45 \ln \mathrm{SL}$ & $0.58^{*}$ \\
\hline & & 30 & SDW x SL & $\ln \mathrm{SDW}=-0.63+0.55 \ln \mathrm{SL}$ & $0.70 *$ \\
\hline & O. urceus & 30 & SIV x SL & $\ln \mathrm{SIV}=-2.04+0.65 \ln \mathrm{SL}$ & $0.75^{*}$ \\
\hline & & 30 & SAW x W & $\ln \mathrm{SAW}=3.41-1.77 \ln \mathrm{W}$ & $0.69 *$ \\
\hline & & 30 & SAL x W & $\ln \mathrm{SAL}=2.17-1.61 \ln \mathrm{W}$ & $0.58 *$ \\
\hline & & 30 & SDW $\times$ W & $\ln \mathrm{SDW}=0.57-0.62 \ln \mathrm{W}$ & $0.72 *$ \\
\hline & & 30 & SIV $x \mathrm{~W}$ & $\ln \mathrm{SIV}=0.99-0.56 \ln \mathrm{W}$ & $0.73 *$ \\
\hline
\end{tabular}


Some particular differences in shell preferences by different species may be attributed both to the size of hermit crabs and to environmental conditions, with the animals looking for protection against the factors to which they are exposed (predation, energy expenditure, osmotic stress and wave action). Furthermore according to Hahn (1998), the experience of inhabiting a specific species of shell predisposes a hermit crab to choose the same species of shell then intraspecific competition could be reduced. On the other hand, when in a free choice situation (laboratory experiments) the shells chosen are those that best fit, as demonstrated in the shell size selection experiments.

The L. loxochelis populations from Brazil and Argentina present differences in the mean size of the specimens, with Argentinean hermit crabs reaching larger sizes $(7.11 \pm 1.29 \mathrm{~mm}$ SL) than the Brazilian ones $(5.77 \pm 0.82 \mathrm{~mm}$ $\mathrm{SL})$. This pattern agrees with the one proposed by Abele (1982), who postulated that the size of crustaceans decrease with decreasing latitude. Furthermore, according to Ohmori et al. (1995), shell utilization patterns would change for different crab sizes even within the same species.

This might explain the differences found in the patterns of shell species preference between both hermit crabs populations. Further studies, comparing in details other aspects of both populations, are needed and will undoubtedly contribute to further resolution of the biological variability in near-shore hermit crabs.

\section{ACKNOWLEDGEMENTS}

Major funding for this project was provided by a grant to FLM by Conselho Nacional de Desenvolvimento Científico e Tecnológico (CNPq) during the International Cooperative Project - CNPq - Prosul Program (Grants 170038/2002-5 and 490340/2004-0) that provided financial support to FLM and MAS during Brazil and Argentina visiting program. ALM and RB are indebted to Fundação de Amparo à Pesquisa do Estado de São Paulo (FAPESP) for Doctoral fellowships. RB and FLM are also indebted to $\mathrm{CNPq}$ for Post Doctoral and for Research on-going fellowships, respectively. MAS is grateful to
UNMDP (EXA 280/04 y 15/E226) and CONICET (Argentina) for support partially. Special thanks to those people who collaborated during the development of this study, especially to Dr. Adilson Fransozo (Paulista State University) and many colleagues from the NEBECC who helped with sampling and the Post-Graduation Course in Comparative Biology of FFCLRP - USP for assistance. We wish to express our gratitude to two anonymous reviewers for critical reading and valuable suggestions on the earlier version of this manuscript.

\section{REFERENCES}

ABELE LG (1982) Biogeography. In: Bliss DE (ed) The biology of Crustacea: systematics, the fossil record, and biogeography. Volume 1: 242-292. Academic Press, London, United Kingdom.

ABRAMS PA (1978) Shell selection and utilization in a terrestrial hermit crab, Coenobita compressus $(\mathrm{H}$ Milne Edwards). Oecologia 34: 239-253.

BERTNESS MD (1980) Shell preference and utilization patterns in littoral hermit crabs of the Bay of Panama. Journal of Experimental Marine Biology and Ecology 48: 1-16.

BERTNESS MD (1981) The influence of shell-type on hermit crab growth rate and clutch size. Crustaceana 40: 197-205.

BLACKSTONE NW (1985) The effects of shell size and shape on growth and form in the hermit crab Pagurus longicarpus. Biological Bulletin 168: 75 90.

CONOVER M (1978) The importance of various shell characteristics to the shell-selection behavior of the hermit crabs. Journal of Experimental Marine Biology and Ecology 32: 131-142.

ELWOOD RW, A MCLEAN \& L WEBB (1979) The development of shell preferences by the hermit crab Pagurus bernhardus. Animal Behaviour 27: 940946.

GARCÍA RB \& FL MANTELATTO (2000) Variability of shell occupation by intertidal and infralittoral Calcinus tibicen (Anomura, Diogenidae) populations. Nauplius 8: 99-105.

GARCÍA RB \& FL MANTELATTO (2001) Shell selection by the tropical hermit crab Calcinus tibicen (Herbst, 1791) (Anomura, Diogenidae) from southern Brazil. Journal of Experimental Marine Biology and Ecology 265: 1-14.

HAHN DR (1998) Hermit crab shell use patterns: response to previous shell experience and to water flow. Journal of Experimental Marine Biology and Ecology 228: 35-51.

HAZLETT BA (1970) The effect of shell size and weight on the agonistic behavior of a hermit crab. Zeitschriff für Tierpsychologie 27: 369-374.

HAZLETT BA (1992) The effect of past experience on the size of shells selected by hermit crabs. Animal Behaviour 44: 203-205

HAZLETT BA (1996) Recent experience and the shell-size preference of hermit crabs. Marine and Freshwater Behaviour and Physiology 28: 177-182. 
LIVELY CM (1988) A graphical model for shell-species selection by hermit crabs. Ecology 69: 1233-1238.

MANTELATTO FL \& LCC DOMINCIANO (2002) Pattern of shell utilization by the hermit crab Paguristes tortugae (Diogenidae) from Anchieta Island, southern Brazil. Scientia Marina 66: 265272.

MANTELATTO FL \& AL MEIRELES (2004) The importance of shell occupation and shell availability in the hermit crab Pagurus brevidactylus (Stimpson, 1859) (Paguridae) population from the southern Atlantic. Bulletin of Marine Science 75: 27-35.

MANTELATTO FL, R ROBLES, R BIAGI \& DL FELDER (2006) Molecular analysis of the taxonomic and distributional status of the hermit crab genera Loxopagurus Forest, 1964 and Isocheles Stimpson, 1858 (Decapoda, Anomura, Diogenidae). Zoosystema 28: 495-506.

MARTINELLI JM \& FL MANTELATTO (1999) Shell utilization by the hermit crab Loxopagurus loxochelis (Diogenidae) in Ubatuba Bay, Brazil. In: Schram FR \& JC Vaupel-Klein (eds) Crustaceans and the biodiversity crisis: 719-731. Brill, Leiden, The Netherlands.

MARTINELLI JM, FL MANTELATTO \& A FRANSOZO (2002) Population structure and breeding season of the South Atlantic hermit crab, Loxopagurus loxochelis (Anomura, Diogenidae) from Ubatuba region, Brazil. Crustaceana 75: 791-802.

MELO GAS (1999) Manual de identificação dos Crustacea Decapoda do litoral brasileiro: Anomura, Thalassinidea, Palinuridea, Astacidea. Plêiade, São Paulo, São Paulo, Brazil, 551pp.

OHMORI H, S WADA, S GOSHIMA \& S NAKAO (1995) Effects of body size and shell availability on the

Associate Editor: Jorge Navarro

Received January 27, 2006; accepted August 25, 2006 shell utilization pattern of the hermit crab Pagurus filholi (Anomura: Paguridae). Crustacean Research 24: 85-92.

ORIANS GH \& CE King (1964) Shell selection and invasion rates of some pacific hermit crabs. Pacific Science 18: 297-306.

REESE ES (1962) Shell selection behaviour of hermit crabs. Animal Behaviour 10: 347-360.

RODRIGUES LJ, DW DUNHAM \& KA COATES (2000) Shelter preferences in the endemic bermudian hermit crab Calcinus verrilli (Rathbun, 1901) (Decapoda, Anomura). Crustaceana 73: 737-750.

SCELZO MA (1976) Larvas de los crustáceos decápodos anomuros identificados en las aguas marinas argentinas. Physis (Argentina) 35: 37-45.

SCELZO MA, FL MANTELATTO \& CC TUDGE (2004) Spermatophore morphology of the endemic hermit crab Loxopagurus loxochelis (Anomura, Diogenidae) from southwestern Atlantic-Brazil and Argentina. Invertebrate Reproduction and Development 46: 1-9.

SIU BFC \& SY LEE (1992) Shell preference and utilization pattern in two hermit crabs, Pagurus trigonocheirus (Stimpson) and Clibanarius bimaculatus (De Haan), on a sheltered rocky shore in Hong Kong. Asian Marine Biology 9: 205-216.

VANCE RR (1972) The role of shell adequacy in behavioral interactions involving hermit crabs. Ecology 53: 1075-1083.

WADA S, H OHMORI, S GOSHIMA \& S NAKAO (1997) Shell size preference of hermit crabs depends on their growth rate. Animal Behaviour 54: 1-8.

WILBER JR TP (1990) Influence of size, species and damage on shell selection by the hermit crab Pagurus longicarpus. Marine Biology 104: 31-39. 
